\title{
Rathke's Cleft Cyst with Non-Hemorrhagic Rupture Resulting in Alteration of Signal Intensity for a Short Period: A Case Report
}

\author{
Kusa Süre İçin Sinyal Şiddeti Değişikliğiyle Sonuçlanan Non-Hemorajik \\ Rüptürlü Ratbke Yarı̆̆ı Kisti: Bir Olgu Sunumu
}

Mizuki KAMBARA, Takeshi MIYAZAKI, Toshiki YAMASAKI, Shinya HAGIWARA, Tsutomu YOSHIKANE, Daikei TAKADA, Yasuhiko AKIYAMA

Shimane University, Faculty of Medicine, Department of Neurosurgery, Izumo, Japan

Corresponding Author: Takeshi MIYAZAKI / E-mail: takeshi@med.shimane-u.ac.jp

\begin{abstract}
In a case of 23-year-old female with Rathke's cleft cyst (RCC), unusual changes with size and morphology on computed tomography (CT) and magnetic resonance images (MRI) were noted in a short period of 3 weeks after spontaneous rupture. The CT noted that the intracystic isodensity was changed to hyperdensity. And MRI showed not only a decrease in size of the lesion but also changing from hypo- and hyperintensity in T1- and T2-weighted images to hyperintensity in both T1- and T2-weighted images. The intraoperative findings disclosed that the cyst content was milky-like, but not hemorrhagic. We considered that the leakage of cyst content to the cerebrospinal fluid pathway caused not only inflammatory reaction but also waxing and waning of both the cyst size and intralesional protein concentration, which resulted in unusual changing CT and MR appearance. We should take into consideration that the nature of RCC can be altered by not only intracystic hemorrhage but also non-hemorrhagic rupture even for a short period.
\end{abstract}

KEYWORDS: Rathke's cleft cyst, Rupture, Nonhemorrhagic

öz

Rathke yarığı kisti olan 23 yaşında bir kadında bilgisayarlı tomografi (BT) ve manyetik rezonans görüntülemede (MRG) büyüklük ve morfolojide spontan rüptür sonrasında 3 hafta gibi kısa bir dönemde olağanüstü değişiklikler görüldü. BT görüntülerinde intrakistik izodansite hiperdansiteye dönüştü. MRG hem lezyon büyüklüğünde bir azalma hem de T1- ve T2- ağırlıklı görüntülerde hipo ve hiperintansiteden hem T1- hem T2- ağırlıklı görüntülerde hiperintansiteye dönüş gösterdi. İntraoperatif bulgular kist içeriğinin hemorajik değil süt gibi olduğunu ortaya çıkardı. Kist içeriğinin serebrospinal sıvı yoluna sızmasının hem enflamatuvar reaksiyona hem de kist büyüklüğü ve intralezyonel protein konsantrasyonunda artış ve azalmaya ve sonuçta olağandışı değişen BT ve MR görünümüne neden olduğunu düşündük. Rathke yarığı kisti tabiatının hem intrakistik kanama hem de hemorajik olmayan rüptür ile kısa bir dönem için bile olsa değişebileceğini dikkate almalıyız.

ANAHTAR SÖZCÜKLER: Rathke yarı̆̆ı kisti, Rüptür, Nonhemorajik

\section{INTRODUCTION}

There are a small number of reports on Rathke's cleft cyst (RCC) with the spontaneous rupture $(1,8,9,14,15,16,17)$. Most of those cases were accompanied by acute inflammatory reactions or hemorrhagic change in peripheral organs such as the pituitary gland. In this case, however, chronic inflammatory reaction was seen although there was no characteristic acute inflammatory reaction such as hypophysitis. This case is the first that represents unusual changes on computed tomography (CT) and magnetic resonance images (MRI) appearance in a short period of 3 weeks before and after spontaneous rupture. The possible etiology of the unusual changes on $\mathrm{CT}$ and MRI appearance is discussed.

\section{CASE REPORT}

A 23-year-old female visited a neighboring physician because of headache and fever between $38^{\circ} \mathrm{C}$ and $39^{\circ} \mathrm{C}$ for about a week. She had a history of 11 years of amenorrhea and repeated meningeal irritations with several times per year. On the initial CT of the head, an isodense cyst was revealed at the sellar region (Figure 1A). The T1- and T2-weighted images at a neighboring physician showed a cystic lesion with mildly low and high intensity, respectively, at the suprasellar region (Figure 1B,C). Postcontrast T1-weghted image showed the thick enhancement of the cyst wall (Figure 1D). The optic chiasm was displaced upward by the mass. She was referred to our hospital. On admission she was free from headache and fever and there was no abnormal neurological finding except bitemporal upper quadrantanopsia. Endocrinological 


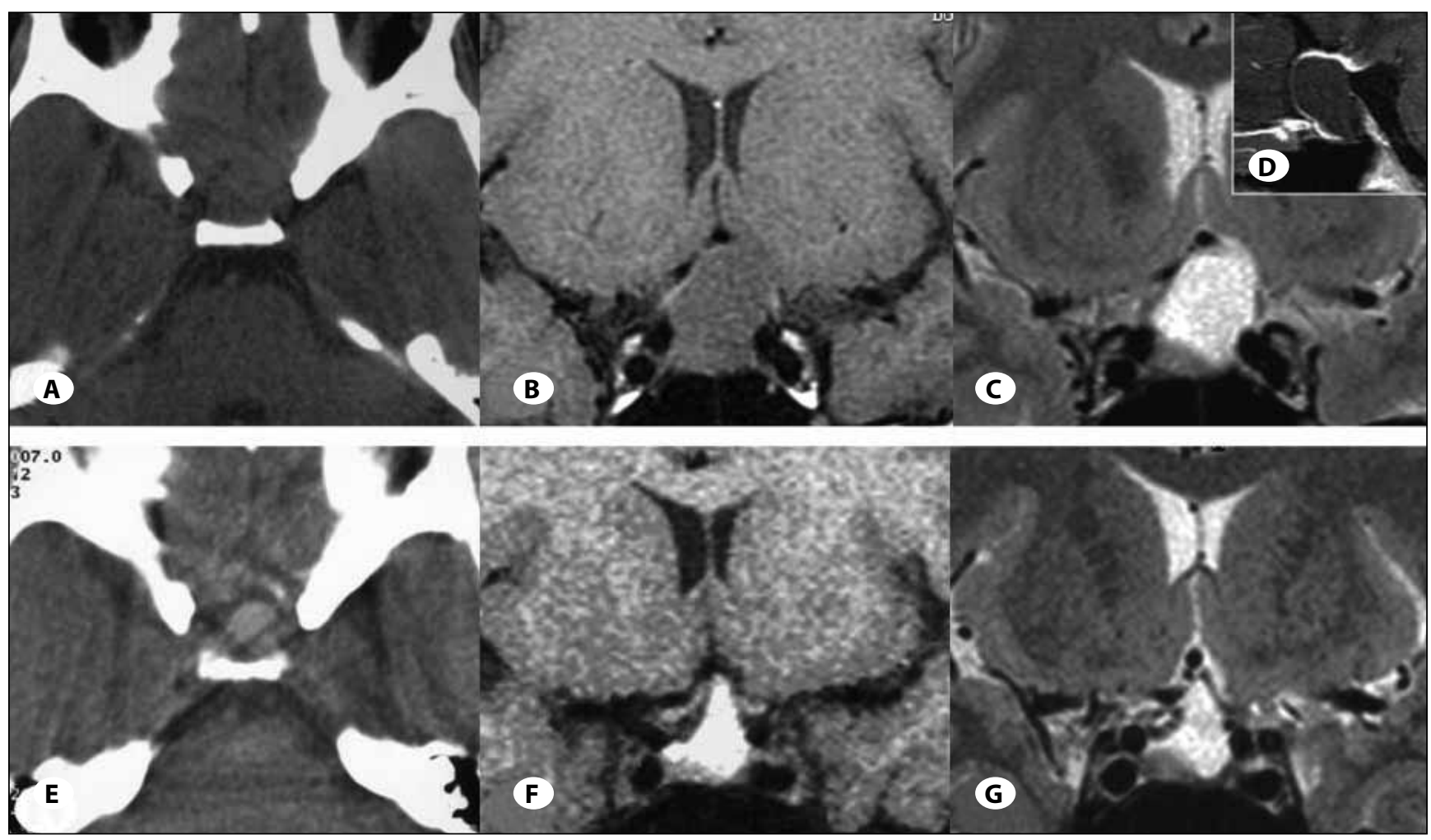

Figure 1: The initial A) CT and coronal B) T1-, C) T2 -weighted images at a neighboring physician. D) Sagittal postcontrast T1-weighted image. Three-week follow-up E) CT and coronal F) T1 -, G) T2 -weighted images.

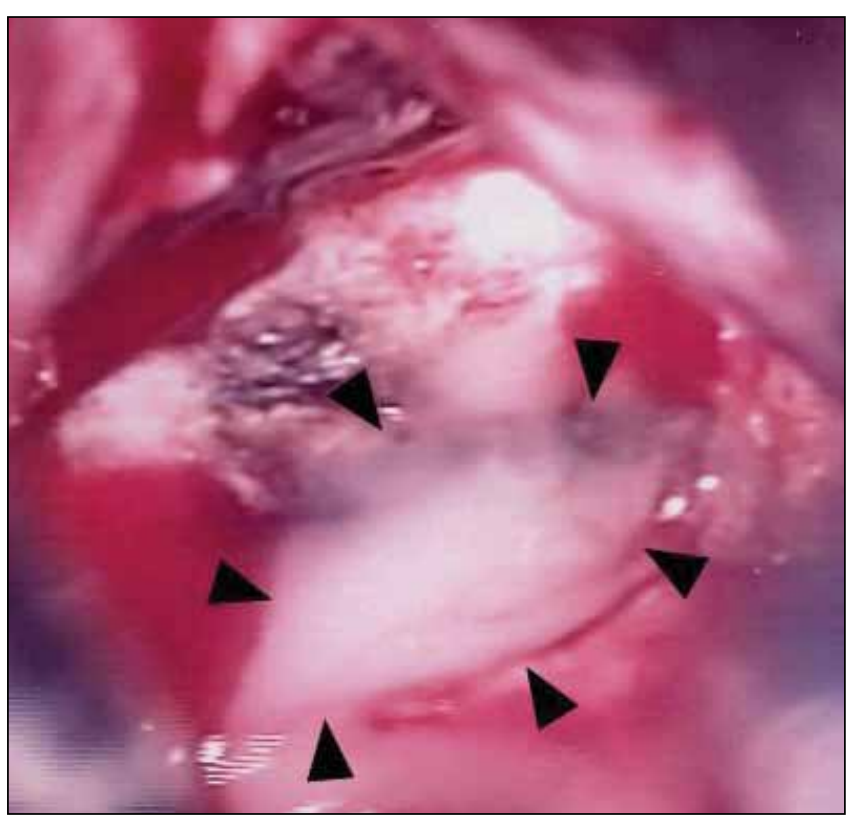

Figure 2: Intraoperative view shows milky-like and pituitary contents flowed out (arrow heads).

examination revealed a mild increase in prolactin and a slight decrease in gonadotropin. Three-week follow-up CT showed that the intracystic isodensity was changed to hyperdensity (Figure 1E). Follow-up MRI showed not only a decrease in size

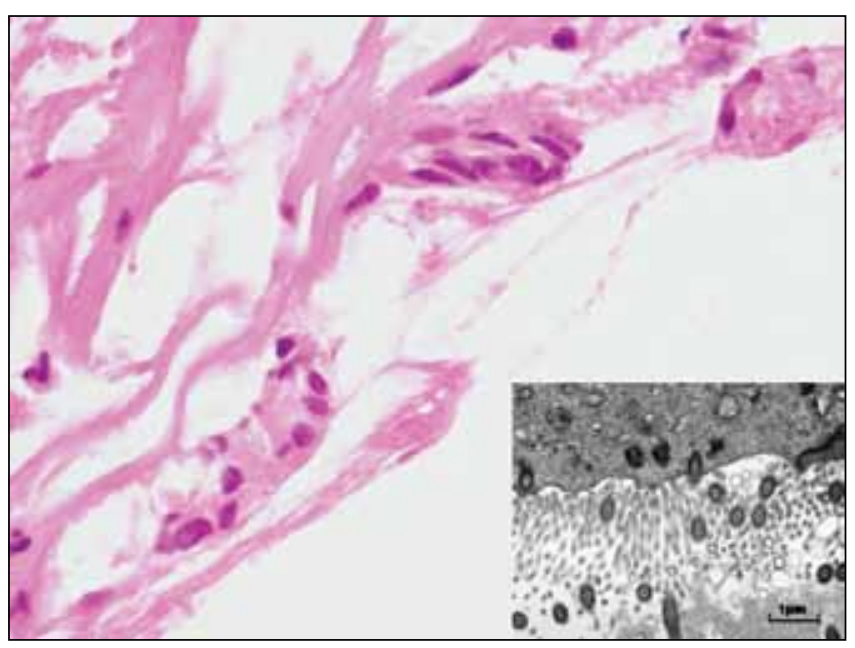

Figure 3: Photomicrograph of hematoxylin-eosin staining $(10 \times 40)$. Electron micrograph (inset) shows a ciliated cell that have microtubules of a $9+2$ configuration $(\times 23,000)$.

of the lesion but also an unusual appearance of the hyperintensity in both T1- and T2-weighted images (Figure 1F, G). The optic chiasm remained displaced by the lesion, however. The clinical course and neuroradiological characteristics suggested intralesional hemorrhage resulted from spontaneous rupture or pituitary apoplexy. Transsphenoidal surgery was performed not only to prevent repeated meningeal irritations 
and pituitary apoplexy but also preserve the optic chiasm. The intraoperative findings revealed a cystic mass with milkylike, but not hemorrhagic fluid (Figure 2). Histological diagnosis was of RCC (Figure 3). A bacillus was not evident from the surgical specimens. Postoperative CT and MRI demonstrated no lesion at the sellar region. Furthermore, postoperative hormonal data was within normal ranges except gonadotropin. Then, she returned to her normal daily activity although the estrogen and progesterone replacement therapy was needed for the persistent amenorrhea.

\section{DISCUSSION}

The variety of radiological findings of RCC according to its content has been described in many reports $(2,7,11)$. There are some reports of spontaneous rupture of RCC that are usually accompanied with acute hypophysits or hemorrhage $(1,8,9,14,15,16,17)$. The rupture was diagnosed retrospectively in almost all and they did not have the radiological findings before the rupture. Nishioka $\mathrm{H}$, et al. has reported the case of hemorrhagic RCC discovered by causing pituitary apoplexy (12). Their case showed slight regression of the lesion after 3 weeks without change of signal intensity. On the other hand, Binning MJ, et al. reported 6 cases of RCC with spontaneous rupture and first mentioned 4 cases of nonhemorrhagic rupture (3). One of them presented slight regression of the intrasellar cyst with change of MRI signal intensity after 3 months. In our case, the symptoms that show hypopituitarism after a spontaneous rupture were not seen. The symptom was only meningeal irritation that she had experienced several times per year until now. It was guessed that the cause to have not resulted in the complete rupture but had remained in rupture like a minor leakage. Solidness of the cyst wall was evidenced by postcontrast T1-weghted image of MRI and pathological examination that showed the thickening cyst wall, proliferation of mesenchymal cells, or chronic inframmatory reactions.

Hama S, et al. (6) reported a case of RCC with diabetes insipidus and they considered that it was caused by inflammatory reaction derived from leakage of the cyst content. Furthermore, Hama S, et al. (5) reported epithelial stratification in RCC is caused by inflammation. Niwa J, et al. (13) reported a close relationship between the thick enhancement of the cyst wall and stratified squamous component or secondary inflammation. Also as our case, the minor leakage of the cyst content had occurred several times before, and it is thought that it led to meningeal irritations, inflammatory reactions and finally strengthening of the cyst wall. It is acceptable to think that mild inflammatory reaction caused by the spontaneous nonhemorrhagic rupture that was caught unexpectedly by the radiological examinations occurred again.

There are two interesting reports. One is about a craniopharygioma that represented increase in size and changes of MRI signal intensity after 6 months (4). The other is about an epithelial intracranial cyst that represented, as seen in our case, a decrease in size and unusual changes on both CT and
MRI appearance 2 years after tumor progression (10). Their quantitative study disclosed the high protein concentration of the cyst fluid. Although it is not RCC, if the phenomenon occurred in the same epithelium cyst is considered, it will be thought that the same mechanism also as our case is applied although the interval for change of signal intensity was only 3 weeks in our case. Taken together, the cause of unusual changing CT and MRI appearance after the spontaneous rupture in our case was considered because the protein concentration in the cyst rose within the short period of time by reduction of the cyst size and induction of the inflammatory reaction by the rupture like minor leakage. When morphology on CT and MRI changes for a short period of time in a patient of RCC with a spontaneous rupture, we should consider the possibility of the rise of protein concentration as differential diagnosis in addition to intralesional hemorrhage. RCC may cause repeated meningeal irritations by repeated nonhemorrhagic rupture.

\section{REFERENCES}

1. Albini $\mathrm{CH}$, MacGillivray $\mathrm{MH}$, Fisher JE, Voorhess ML, Klein DM: Triad of hypopituitarism, granulomatous hypophysitis, and ruptured Rathke's cleft cyst. Neurosurgery 22:133-136, 1988

2. Asari S, Ito T, Tsuchida S, Tsutsui T: MR appearance and cyst content of Rathke cleft cysts. J Comput Assist Tomogr 14: 532-535, 1990

3. Binning MJ, Liu JK, Gannon J, Osborn AG, Couldwell WT: Hemorrhagic and nonhemorrhagic Rathke cleft cysts mimicking pituitary apoplexy. J Neurosurg 108:3-8, 2008

4. Chatterjee S, Kesavadas C, Menon G, Nair S, Radhakrishnan $\mathrm{VV}$ : Changing signal intensity of a craniopharyngioma. Neurol India 58:468-470, 2010

5. Hama S, Arita K, Nishisaka T, Fukuhara T, Tominaga A, Sugiyama K, Yoshioka H, Eguchi K, Sumida M, Heike Y, Kurisu $\mathrm{K}$ : Changes in the epithelium of Rathke cleft cyst associated with inflammation. J Neurosurg 96:209-216, 2002

6. Hama S, Arita K, Tominaga A, Yoshikawa M, Eguchi K, Sumida M, Inai K, Nishisaka T, Kurisu K: Symptomatic Rathke's cleft cyst coexisting with central diabetes insipidus and hypophysitis: Case report. Endocr J 46:187-192, 1999

7. Hayashi $Y$, Tachibana O, Muramatsu N, Tsuchiya H, Tada M, Arakawa Y, Suzuki M, Yamashita J: Rathke cleft cyst: MR and biomedical analysis of cyst content. J Comput Assist Tomogr 23:34-38, 1999

8. Kurisaka M, Fukui N, Sakamoto T, Mori K, Okada T, Sogabe K: A case of Rathke's cleft cyst with apoplexy. Childs Nerv Syst 14:343-347, 1998

9. Yuyama R, Kojima H, Mizutani T, Suzuki Y, Miki Y: Secondary pan-hypophysitis caused by rupture of Rathke's cleft cyst: Case report. No Shinkei Geka 30:95-99, 2002

10. Macaulay RJ: Ruptured Rathke's cleft cyst: A possible cause of Tolosa-Hunt syndrome. Clin neuropathol 16:98-102, 1997

11. Merino S, Arrazola J, Arenal F, Moreno MJ, Saldana C, Martinez A, Pascual A: Unusual changing CT and MR appearance of an epithelial intracranial cyst. Eur J Radiol 38:41-46, 2001 
12. Nakasu Y, Isozumi T, Nakasu S, Hanada J: Rathke's cleft cyst: Computed tomographic scan and magnetic resonance imaging. Acta Neurochir (Wien) 103:99-104, 1990

13. Nishioka $H$, Ito $H$, Miki T, Hashimoto $T$, Nojima $H$, Matsumura $\mathrm{H}$ : Rathke's cleft cyst with pituitary apoplexy: Case report. Neuroradiology 41:832-834, 1999

14. Niwa J, Tanabe S, Ibayashi Y, Hashi K: Clinicopathological findings in symptomatic Rathke's cleft cyst: Correlation between enhancement effects on MRI and histopathology of the cyst wall. No Shinkei Geka 24:125-133, 1996
15. Pawar SJ, Sharma RR, Lad SD, Dev E, Devadas RV: Rathke's cleft cyst presenting as pituitary apoplexy. J Clin Neurosci 9:76-79, 2002

16. Roncaroli F, Bacci A, Frank G, Calbucci F: Granulomatous hypophysitis caused by a ruptured intrasellar Rathke's cleft cyst: Report of a cause and review of the literature. Neurosergery 43:146-149, 1998

17. Rosales MY, Smith TW, Safran M: Hemorrhagic Rathke's cleft cyst presenting as diplopia. Endocr Pract 10:129-134, 2004 